\title{
Removal of High Concentrations of Sulfate from Wastewater: Evaluating Different Methods and Proposing the Best Option
}

\author{
Leila Davarpanah $^{1^{*}}$, Soma Taherian², Elham Abdollahzadeh Sharghi ${ }^{1}$ \\ 1. Assistant Professor, Environmental Group, Energy Department, Materials and \\ Energy Research Center, Karaj, Iran \\ 2. MSc Graduate of Renewable Energy Engineering, Energy department, Materials and \\ Energy Research Center, Karaj, Iran \\ *E-mail: l.davarpanah@merc.ac.ir \\ Received: 25 Jul 2018 ; Accepted: 21 Nov 2018
}

\begin{abstract}
Background and Objectives: Industrial wastewaters containing high amounts of compounds such as sulfate can cause serious risks to human health and environment. Therefore, proposing practical solutions with the lowest cost and the highest efficiency for pollutants removal is of special importance. The purpose of this study is to find a suitable method for treatment wastewater containing very high amounts of sulfate.

Methods: This research is an experimental-research study in which four different practical methods have been investigated for treatment of sulfate containing wastewater including chemical precipitation with lime, electrocoagulation, biological degradation and thermal distillation.

Results: After examining the performance of different methods and considering the special characteristics of wastewater, the results showed that the methods of chemical precipitation (removal efficiency of $5 \%$ ) and electrocoagulation (removal efficiency of $7 \%$ ) were less efficient. The distillation process also showed an acceptable performance in removing TDS and sulfate from this wastewater (removal efficiency of $98.7 \%$ ) and the biological method could function well after wastewater dilution (the removal percentage of sulfate in the first 24 hours for wastewater with dilutions of 10, 25 and $50 \%$, are about 55, 40 and $17 \%$, respectively).

Conclusion: According to the results obtained from this study, methods of chemical precipitation and electrocoagulation are proposed only as a pre-treatment method and biological treatment can be used as a supplementary treatment after pre-treatment. Distillation is also not recommended as a practical method due to high cost and energy consumption.

Keywords: Sulfate removal, Wastewater, Chemical precipitation, Electrocoagulation, Biological reduction, Distillation
\end{abstract}




\title{
حذف سولفات با غلظت بالا از فاضلاب: \\ ارزيابى روشهاى مختلف و ييشنهاد ززينه برتر
}

\author{
ليلا داوريناه"'، سوما طاهريان؛، الهام عبداله زاده شرقى' \\ ' استاديار گروه محيط زيست، بزّوهشكده انرزى، يزوهشگاه مواد و انرزى، كرج، ايران

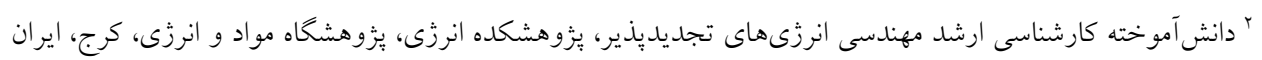

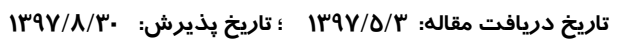

\section{קكيد}

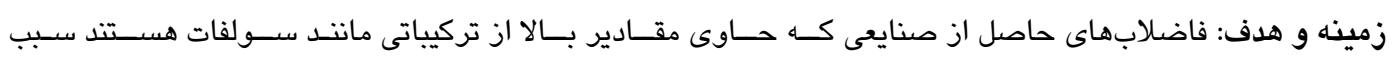

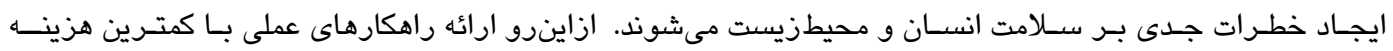

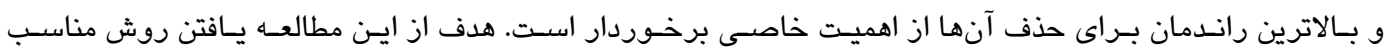

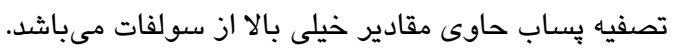

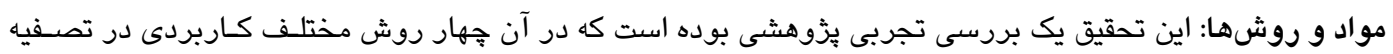

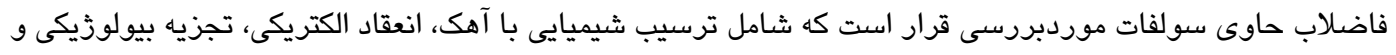

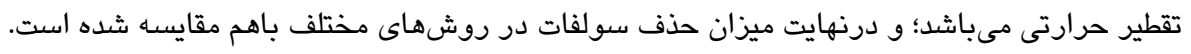

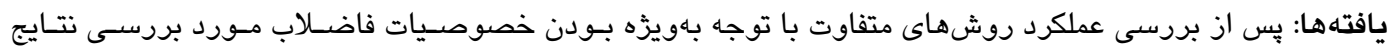

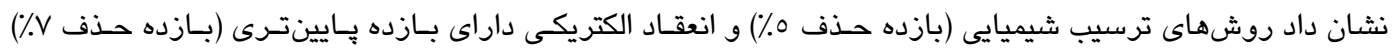

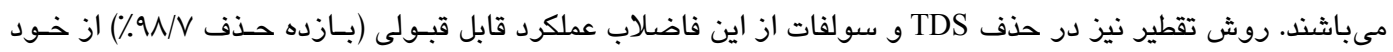

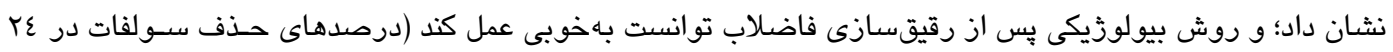

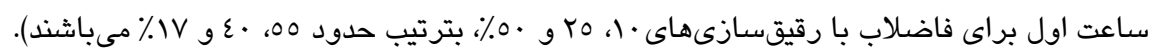

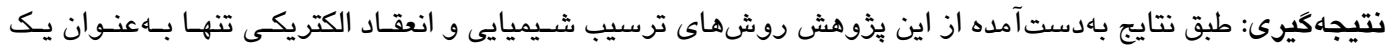

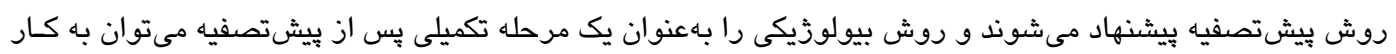

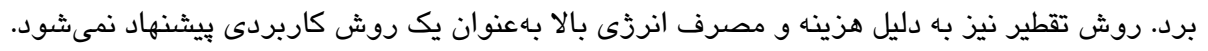

كلمات كليدى: حذف سولفات، فاضلاب، ترسيب شيميايى، انعقاد الكتريكى، كاهش بيولوزيكى، تقطير 
فاضلاب و آلودكى منـابع آبسى، لـزوم نيـل بـه اسـتانداردهاى

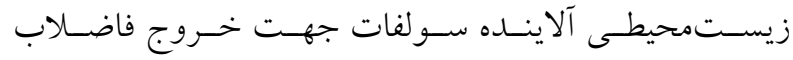

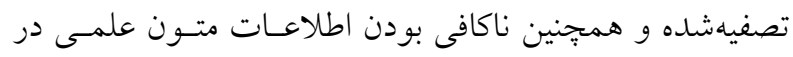

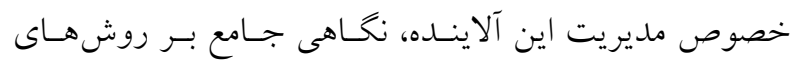

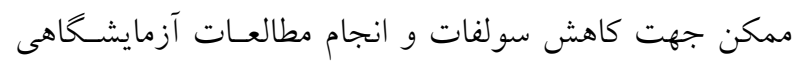
بيشازييش احساس مىشود. ازايـنرو، هـــف اصـلى در ايـن مطالعه دستيابى به دانش فنى و انتخاب روش تصفيهاى مناسب جهت تصفيه فاضلاب حاوى سولفات بــا غلظـت بـالا همــــاه باقابليت اجرا ازلحاظ فنى و اقتصادى به كونسهاى كـه كمتـرين

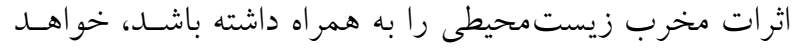
بود. روشهايى كه براى حذف سولفات در اين مطالعه بررسى

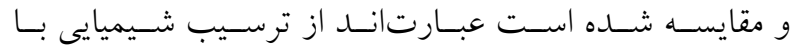
آهك/سنخ آهك، فرايند انعقاد الكتريكى، احيـاء بيولـوزيكى و

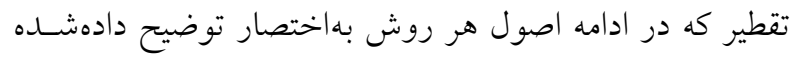

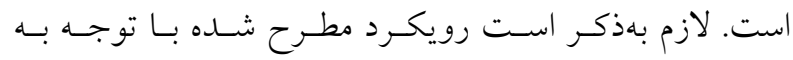

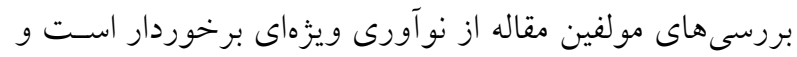

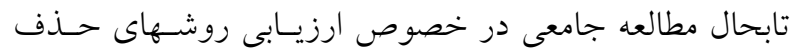
سولفات با غلظت بالا در متون علمى انجام نشده است.

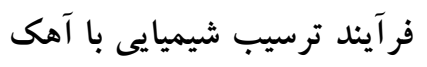

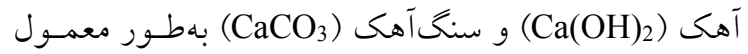

براى ختشى سازى استفاده مى شوند، همجنـين مسىتسوان از ايسن

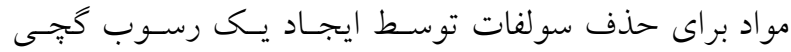
طبق معادلات او ب كمك كرفت: $\left(\mathrm{CaSO}_{4} 2 \mathrm{H}_{2} \mathrm{O}\right)$ $\mathrm{Ca}(\mathrm{OH})_{2}(\mathrm{~s})+\mathrm{H}_{2} \mathrm{SO}_{4} \rightarrow \mathrm{CaSO}_{4} \cdot 2 \mathrm{H}_{2} \mathrm{O}(\mathrm{s})$

$\mathrm{CaCO}_{3}(\mathrm{~s})+\mathrm{H}_{2} \mathrm{SO}_{4}+\mathrm{H}_{2} \rightarrow \mathrm{CaSO}_{4} \cdot 2 \mathrm{H}_{2} \mathrm{O}(\mathrm{s})+\mathrm{CO}_{2}(\mathrm{~g})(\mathrm{r})$ سطح غلظت سولفات توسط محلـول كجى كـاهش داده مىشود كه وابسته به تركيبات و قدرت يونى محلول است. بـاس الـا

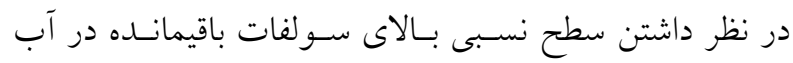

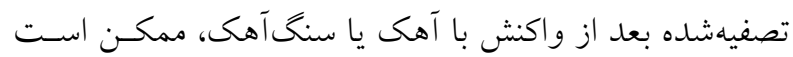

\section{مقدمه}

داشتن منابع آب سالم براى حفظ كيفيت محسيطزيست و

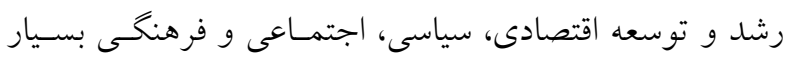
ضرورى است. رشد سريع صنايع كشور كه اغلب بدون توجسه توسه

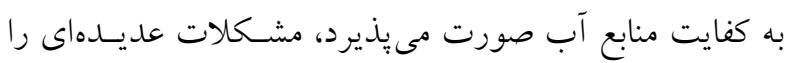

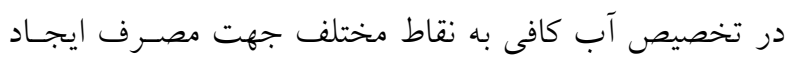

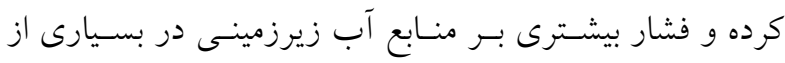

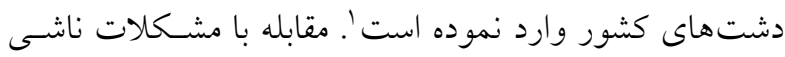

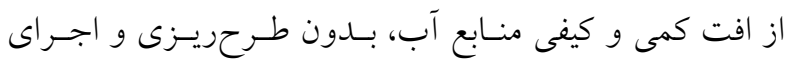
برنامههاى عملى كاهش مصرف، تصـفيه فاضـلاب و اسـتفاده

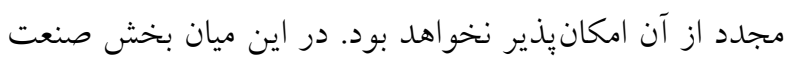
نقش عمدهاى در آلودكى ذخاير آب شيرين داشته و در مقابـل بيشترين يتانسيل را براى كاهش مصرف و اجراى برنامـهـــاى

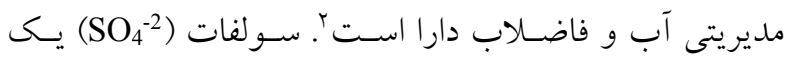
تركيب متداول و غير سمى اسـت كـه بطـور طبيعى در آب و فاضلاب يافت مىشود و در فاضلاب صنايعى هميجون معـدن،

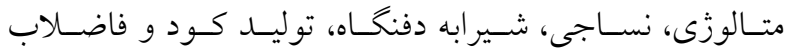

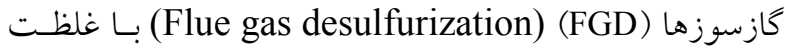

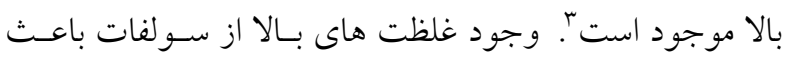

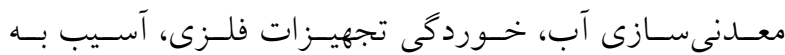

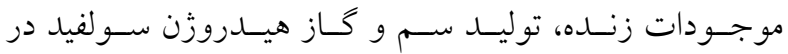

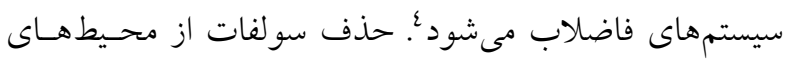

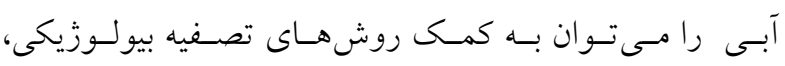
فيلتراسيون، تبادل يونى /جذب و ترسيب شـيميايى انجـام دادّا؟

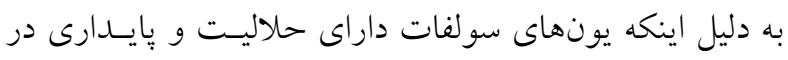

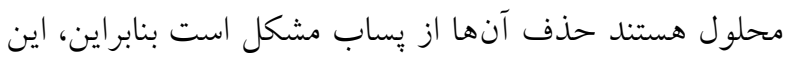

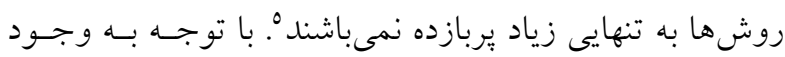

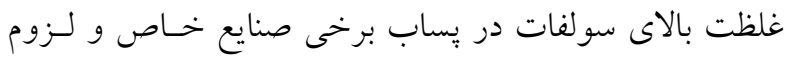

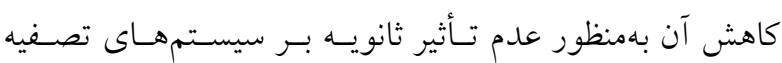


هيدروزن سـولفيد (H2S) اسـتوار اسـت. در حقيقـت كـاهش

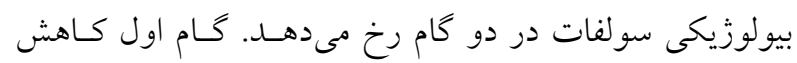
سولفات توسط احيـاى وإياشـى توسط بـاكترىهـاى كاهنــه سولفات (SRB) طبق معادله V انجام مى شود: $4 \mathrm{CH}_{3} \mathrm{OH}+3 \mathrm{SO}_{4}^{2-} \rightarrow 4 \mathrm{HCO}_{3}^{-}+3 \mathrm{HS}^{-}+\mathrm{H}^{+}+4 \mathrm{H}_{2} \mathrm{O}$

سبس در مرحله دوم سـولفيد توليدشـــه طـى مرحلـه اول

توسط باكترىهـاى كمـوتروف (Chemotrophic bacteria)

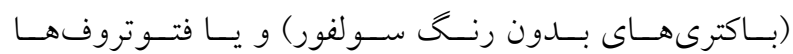
(بــاكترىهــاى بــنفش و ســبز (Phototrophic bacteria) سولفورى) به سولفور عنصرى (S) بر اساس معادلـه V اكسـيد

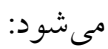
$2 \mathrm{HS}^{-}+\mathrm{O}_{2}(\mathrm{~g})+2 \mathrm{H}^{+} \rightarrow 2 \mathrm{~S}(\mathrm{~s})+2 \mathrm{H}_{2} \mathrm{O}$

$2 \mathrm{HS}^{-}+\mathrm{CO}_{2}(\mathrm{~g})+2 \mathrm{H}^{+} \rightarrow 1 / 6 \mathrm{C}_{6} \mathrm{H}_{12} \mathrm{O}_{6}+2 \mathrm{~S}(\mathrm{~s})+\mathrm{H}_{2}$

mg/L در شرايط كمبود اكسيزن (اكسيزن محلـول كمتـر از 1/•)، مو گرد جامد (S) مهمترين فراورده اكسيداسيون سولفيد است، درحالى كه سولفات تحت شرايط كمبود سولفيد تشـكيل مىشود. حذف سولفيد بعد از كام اول با تهنشينى سولفيد آهن فلزى (MeS) و عارى سازى HeS نيز مى تواند انجام شـود. در حضـور سـولفات، بـاكترىهــاى اسـتاتسـاز و متـانسـاز بــا باكترىهاى SRB براى مصرف سوبسترا رقابت مى كننـد. SRB ها بـاطور مؤثرى با متان سازها براى سوبستر اهاى معمول (كاز هيدروزن و استات) رقابت مى كنند.

\section{روش تقطير}

فرآيند تبخير - تبلور يك فر آينـد جداسـازى شـناختهشــه

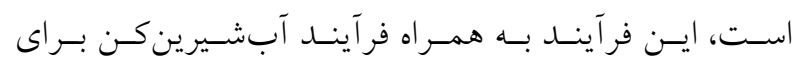

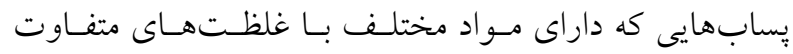
هستند، استفاده مىشود. با تبخير آب، غلظت نمكهاى معدنى محلول ماننــ سـولفات و كلرايـــ قليـايى افـزايش مسىيابـــ و يسازاين فرآيند تبلور آغاز مىشود. ايسن سيستم را مسىتـوان
لازم باشد كه اين فرآيند بهعنوان يكى مرحله بيشتصفيه بــراى فاضلابهايى با غلظت بالاى سولفات در نظر كرفته شود(7).

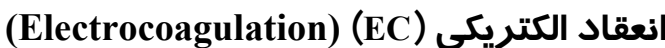

فرآيند انعقاد الكتريكى يك نوع خــاص از فر آينـد تصـفيه هست كه در آن عمل انعقاد از طريق انحلال الكترود فلزى آند كه با اعمال جريان به الكترودهاى آند-كاتــد انجـام مسىشـود، صورت مسى گيـردّا. در مقايسـه بــا روش هــاى متــداول انعقــاد شيميايى، انعقاد الكتريكى داراى مزاياى ازجملـه: ميـزان كمتـر يونهاى منعقدكننده موردنياز، ميزان بيشتر حذف آلاينده، عدم نياز به اضافه كـردن مـواد شـيميايى و در نتيجـه جلـو گيرى از ايجاد آلودگى ثانويه و كاهش ميزان لجن توليــى كـه نيازمنــ دفع، است، زمان واكنش كم و بنابراين اندازه كوجيكتر راكتـور، بهرهبردارى و نخهارى ساده، قابليت انتخاب، انعطاف يـذيرى، ساز گارى با محيطزيست، ايمنى و مقرونبهصرفه بودن از نظـر اقتصـادى اسـتُ. در ايسن روش نيـازى بـهه اسـتفاده از مـو اد شيميايى به عنوان منعقد كننده نيست و يونهاى فلزى حاصـل از عبور جريـان مسـتقيم از سـلول الكتروشـيميايى، هيـدروليز كرديله و يونهاى فلزى هيدروكسـيد توليــ مسى كنــد. ميـزان

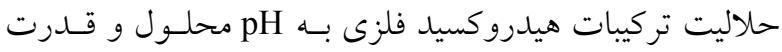
يونى آن وابسته است . بطور كلى مكانيسمهاى ذيل مى توانتــ بيانكر فراينــ انعقـاد الكتريكـى باشــند. در ايسن معـادلات

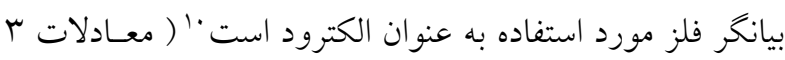

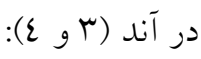

$M(s) \rightarrow \mathrm{M}^{\mathrm{n}+}(\mathrm{aq})+\mathrm{ne}^{-}$

$2 \mathrm{H}_{2} \mathrm{O}(\mathrm{I}) \rightarrow \mathrm{O}_{2}(\mathrm{~g})+4 \mathrm{H}^{+}(a q)+4 e^{-}$

در كاتد (0 و 7):

$M^{\mathrm{n}+}(\mathrm{aq})+\mathrm{ne}^{-} \rightarrow \mathrm{M}(\mathrm{s})$

$2 \mathrm{H}_{2} \mathrm{O}+2 \mathrm{e}^{-} \rightarrow \mathrm{H}_{2}(\mathrm{~g})+2 \mathrm{OH}^{-}$

حذف سولفات توسط فر آيند كاهش بيولوزيكى

سيستمهاى حـذف بيولـوزيكى سـولفات بــر بايـهـ كـاربرد

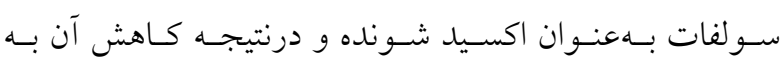


همـانطـور كـه در جـدول ا مشـاهلده مسىشـود يُسـاب موردمطالعه، با توجه به خصوصسيات فيزيكى و شـيميايى كـه

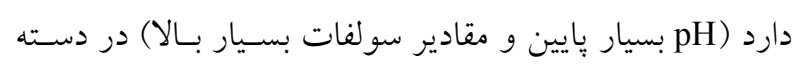
يساب هاى خاص قرار مى گيرد كـه تصـفيه آن لزومـاً نيـاز بـهـ

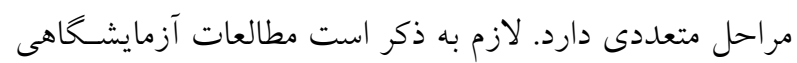
با هدف حذف سولفات از اين فاضلاب انجام كرفت و حذف بر

$$
\text { COD }
$$

\section{روش انعقاد شيميايى (آهك زنى)}

جهت انجام تستهاى انعقاد شيميايى محلـول آهكى بـــ

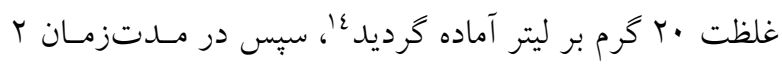
دقيقه با دور 10.rpm در دستخاه جار عمل اختلاط انجامشد.

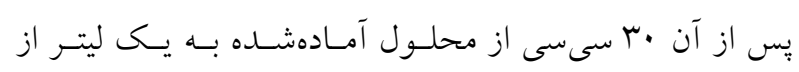

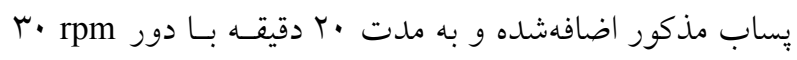
عمل اختلاط صورت كرفت.
براى يسابـهايى كه داراى غلظت بـالايى از نمـكهــا هسـتند

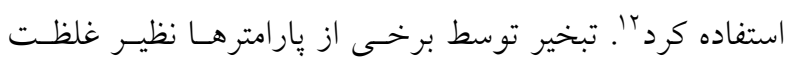

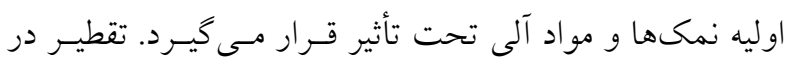
خلأ نوعى از فناورى مى باشد كه توسـط ايسن روش مسى تـوان يساب را در دمايى كمتر تبخير كردّا". همانطور كه در ادامه بيان خواهد شد، نمونه فاضلاب تهيه شده جهت مطالعـه حـاوى مقـادير بسـيار بـالايى از سـولفات مىباشد. بنابراين در اين مقالـه هـدف يـافتن روشسى مناسـب جهت كاهش غلظت سولفات در اينخونه فاضـالابهـاى ويـزّه

\section{مواد و روشها}

نمونه فاضلاب مورداستفاده از واحد اسـيد اويـل يكسى از كارخانهاى توليد و تصفيه روغن خوراكى تهران تهيه گرديــ و يس از حمل به آزمايشـخاه در دمـاى ع درجـه سـانتى گـراد نخهارى كرديد. مشخصات فاضـلاب مـوردنظر در جـدول ا ارائه شده است.

جدول ا: خصوصيات فاضلاب خروجى بخش اسيد اويل

\begin{tabular}{|c|c|c|}
\hline واحد & غلظت & بارامتر \\
\hline --- & $r / 07$ & $\mathrm{pH}$ \\
\hline $\mathrm{mS} / \mathrm{cm}$ & $7 \cdot / 7$ & هدايت \\
\hline $\mathrm{g} / \mathrm{L}$ & $\varepsilon r$ & TDS \\
\hline$\%$ & $\varepsilon \cdot / r$ & شورى \\
\hline $\mathrm{mg} / \mathrm{l}$ & $171 \ldots$ & COD \\
\hline NTU & $\varepsilon r V / 0$ & كدورت \\
\hline $\mathrm{mg} / \mathrm{l}$ & ov... & سولفات \\
\hline $\mathrm{mg} / 1$ & $|\varepsilon| V$. & فسفات \\
\hline $\mathrm{mg} / 1$ & $\varepsilon r / 0$ & كلر ايد \\
\hline $\mathrm{mg} / 1$ & 117 & نيترات \\
\hline $\mathrm{g} / \mathrm{L}$ & $r / 00$ & TSS \\
\hline
\end{tabular}

جدولr: شرايط آزمايشات انعقاد الكتريكى

\begin{tabular}{|c|c|c|c|}
\hline pH & شدت جريان (A) & تعداد الكترود & نوع الكترود \\
\hline$\wedge$ & 1. & $\varepsilon$ & استيل \\
\hline
\end{tabular}




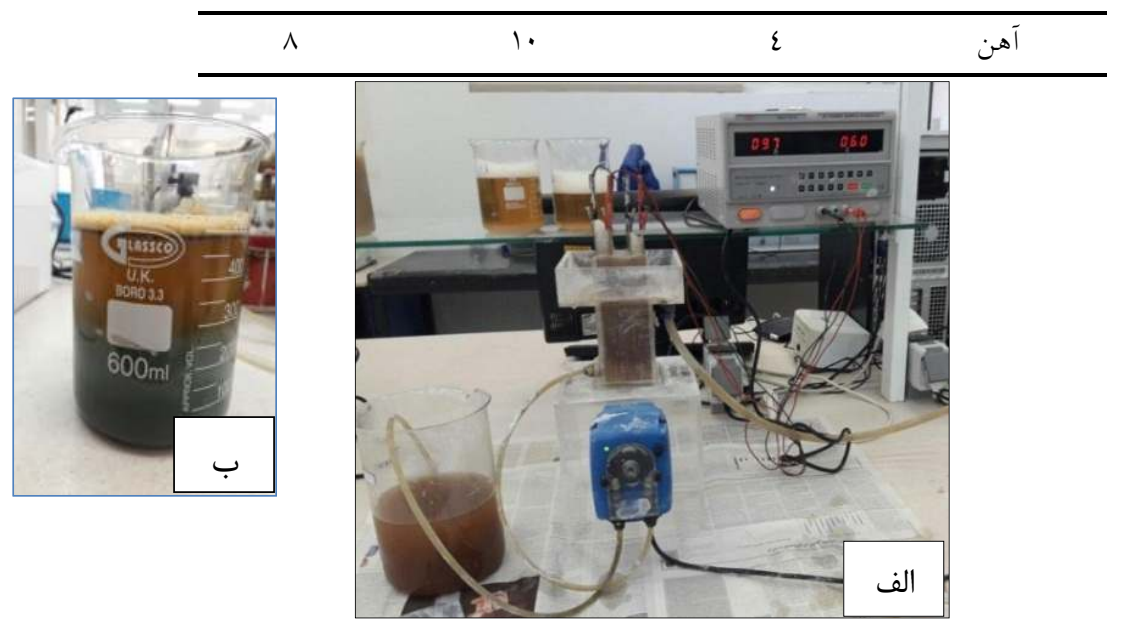

شكل ا: شماتيك فرايند تصفيه فاضلاب حاوى سولفات توسط سيستم انعقاد الكتريكى (الف) و فاضلاب خروجى از سيستم با الكترود آهن (ب)

باكترىهاى احياكننده سولفات از مخلوط ميكروبى گرفته شده از قسمت لجن بر گشتى تصفيهخانه يكى از كشتار گاههـاى دام و طيور در جنوب تهران فراهم كرديد. به علت غلظـت بـالاى

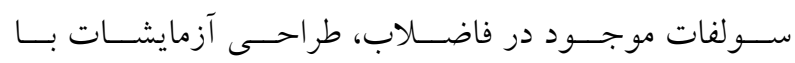

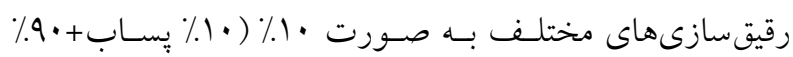

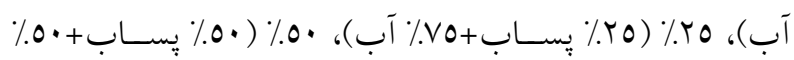
آب) و خالص (بلدون آب) و با دو بـار تكــرار انجـام گرديـد. سرم باتلها با دميدن كاز نيتروزن بىهوازى شد و درب بـ بـ آنهـا محكم بسته شد. سبس نمونههـا در شـيكر انكوبـاتر (Korea-

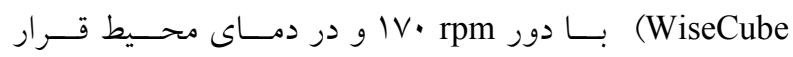
دادهدند. شكل Y تصاوير نمونهها را نشان مىدهد.

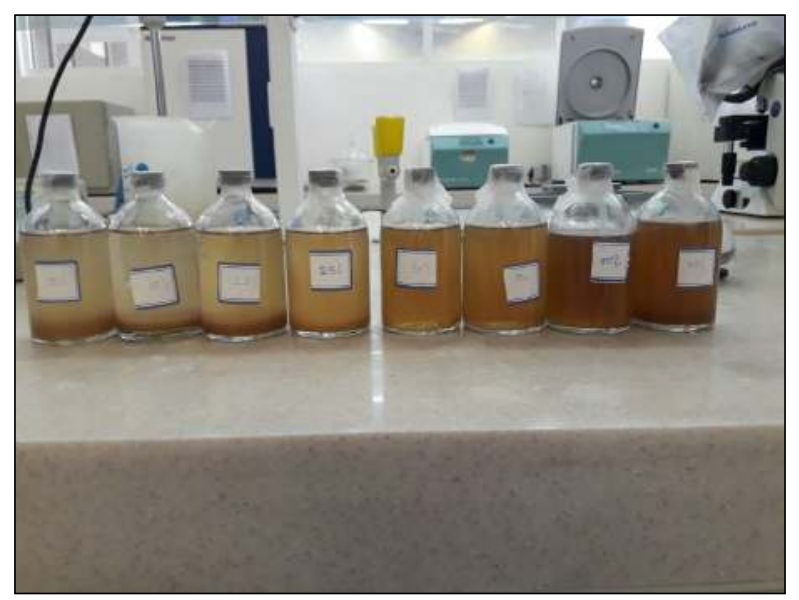

\section{روش انعقاد الكتريكى}

در اين تحقيق بررسى حسذف سـولفات بـه كمـك فرآينــ انعقاد الكتريكى در يـك راكتـور آزمايشـحاهى انجـام كرديـــ. جهت تنظيم pH يسـاب مورداسـفاده از

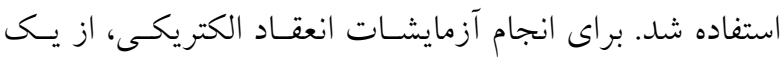

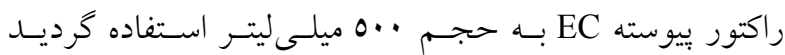
(شكل (). بهمنظور تأمين جريان الكتريسيته مـوردنظر از منبـع تغذيه (MASTECH-HY36010MR-China) استفاده شد. در اين سيستم از ع عدد الكترود از جنس استيل و آهـن بـا ابعـاد

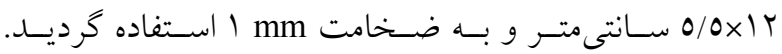
ناخـالصسىهـاى سـطح الكترودهــا قبـل از اسـتفاده در راكتـور بهوسيله سنباده تميز و سبس با اسيد هيدروكلريك يك نرمـال و آب مقطر شستشو داده شد. شرايط آزمايشات انجامشــده در جدول r ارائه شده است.

\section{روش بيولوزيكى}

در اين روش بهمنظور بررسى حذف بيولـوزيكى سـولفات 11. در ابتـا بـا تهيـه يـك مجموعسهاى از ظـروف شيشـهاى ميلى ليترى (با حجم مفيد · ․ ميلىليتر)، خوراكدهى مناسـب

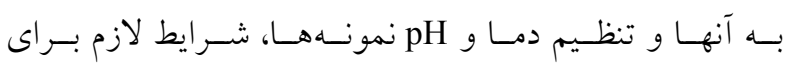


UV/VIS Spectrometer ) استفاده از دستخاه اسسبكتروفتومتر instrument Ltd, England P6 كرفت

\section{يافتهها}

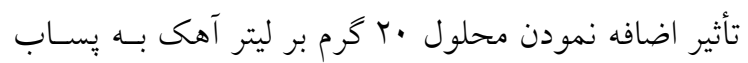

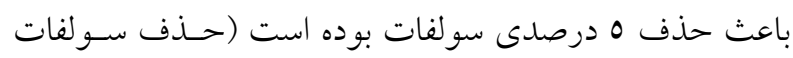

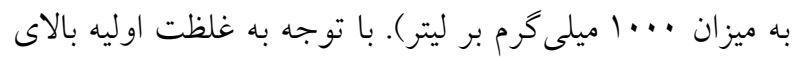

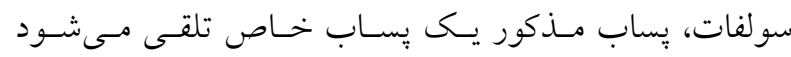

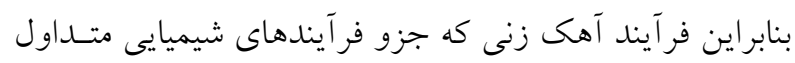
بهمنظور انعقـاد و لختـهسازى محسـوب مسى شـود در اينجـا به تنهايى براى حذف مقادير بالاى سولفات جوابخو نيست. از

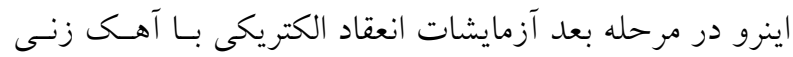

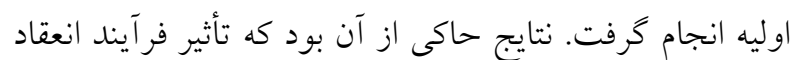

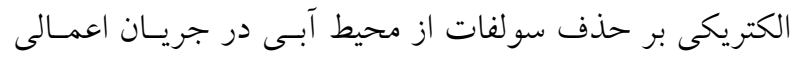

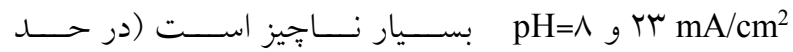


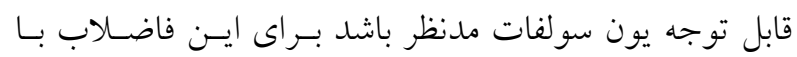

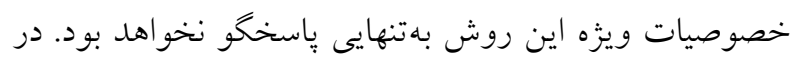

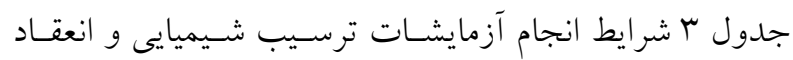
الكتريكى نشان داده شده است.

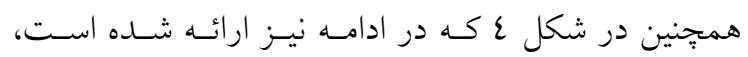

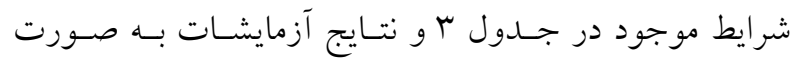
نمودار ستونى رسم شده است.

\section{نتــايج ميـزان غلظــت ســولفات و TDS نهـــيى در آزمايشات}

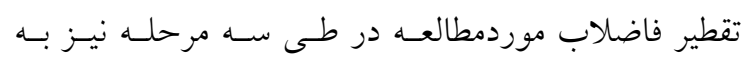

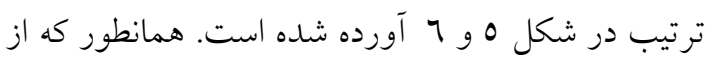

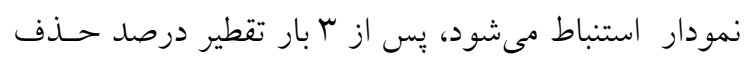

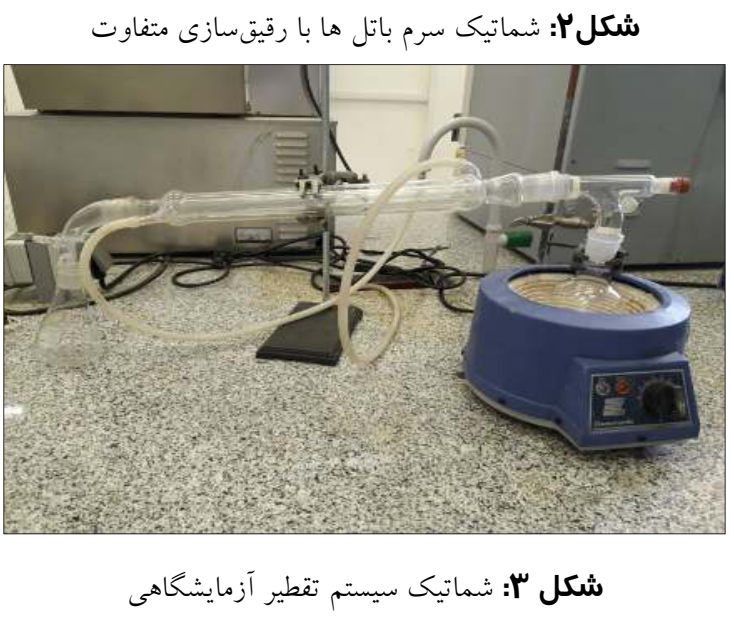

روش تقطير

در اين روش به كمك يك دستخاه مبرد آزمايشگاهى و در دماى •r| إدرجه سانتى گراد عمل تقطير جهت جداسازى يـون

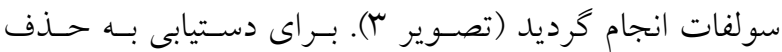
بيشتر عمل تقطير طى سه مرحله تكرار كرديد. تصوير سيستم تقطير مورد استفاده در شكل ب نشان دادهشده است. در بايان هر مرحله از آزمايشات مقــار TDS نمونـهـهـاى

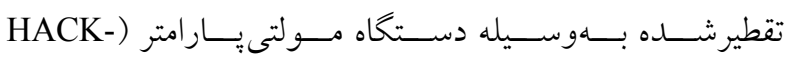
(HQ40d,USA

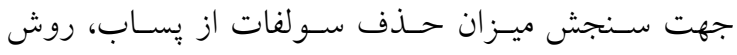
توربيـديمترى (Method 9038-EPA) بـا استفاده از مححلـول مئل

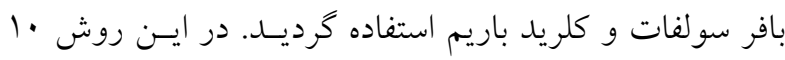

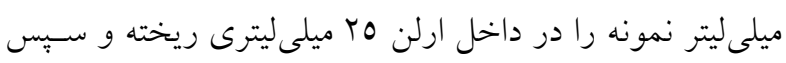

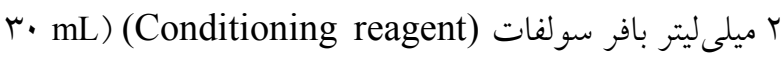

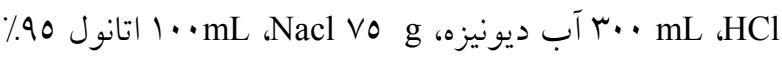
و م كليسرول) به آن اضافه كرديد. سـبس نمونسههـا بـا

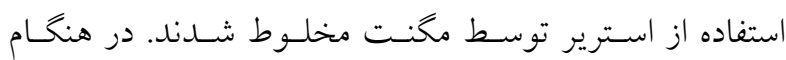

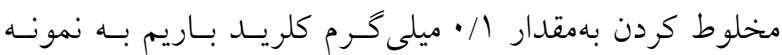

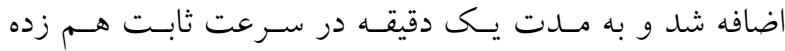

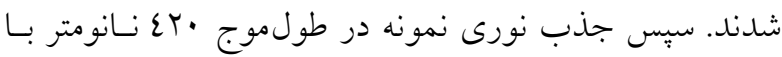




$$
\begin{aligned}
& \text { سولفات به 9N/V٪ مىرسد كه نشانخر موثرتر بودن ايسن روش } \\
& \text { نسبت به ساير روش ها مىباشد. }
\end{aligned}
$$

\begin{tabular}{|c|c|}
\hline شرايط انجام آزمايشات انعقاد الكتريكى & شماره آزمايش در نمودار ع \\
\hline 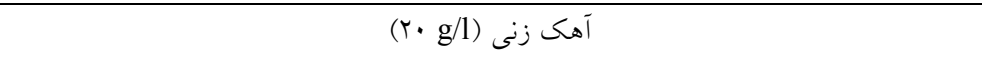 & 1 \\
\hline آهك زنى بعد از EC، استفاده از كمك منعقد كننده كاتيونى، pH =T/0 & r \\
\hline آهك زنى بعد از EC=r/0 آ & r \\
\hline آهك زنى قبل از EC=r/0، & $\varepsilon$ \\
\hline آهك زنى قبل از EC، استفاده از كمك منعقد كننده كاتيونى، pH=r/0 & 0 \\
\hline آهى زنى قبل از EC، استفاده از كمك منعقد كننده كاتيونى، pH=^ & 7 \\
\hline آهك زنى (g/1 l) قبل از EC، كمك منعقدكننده كاتيونى pH=^ ، الكترود استيل & v \\
\hline بدون آهك، pH=V الكترود استيل & $\wedge$ \\
\hline 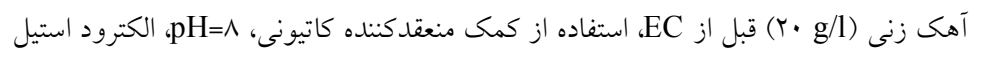 & 9 \\
\hline بدون آهك، pH=r/0 ، الكترود استيل & $1 \cdot$ \\
\hline آهك زنى (g/l ·ع) قبل از EC ، استفاده از كمك منعقدكننده كاتيونى، pH=V ، الكترود استيل & 11 \\
\hline
\end{tabular}

جدول سا: نتايج آزمايشات ترسيب شيميايى و انعقاد الكتريكى بر نمونه فاضلاب

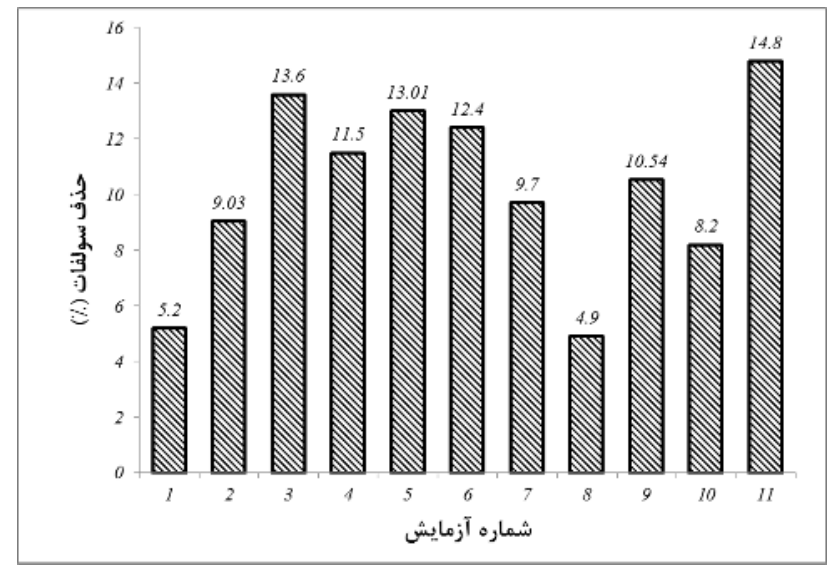

شكل ع: نتايج درصد حذف سولفات به كمك روش انعقاد الكتريكى

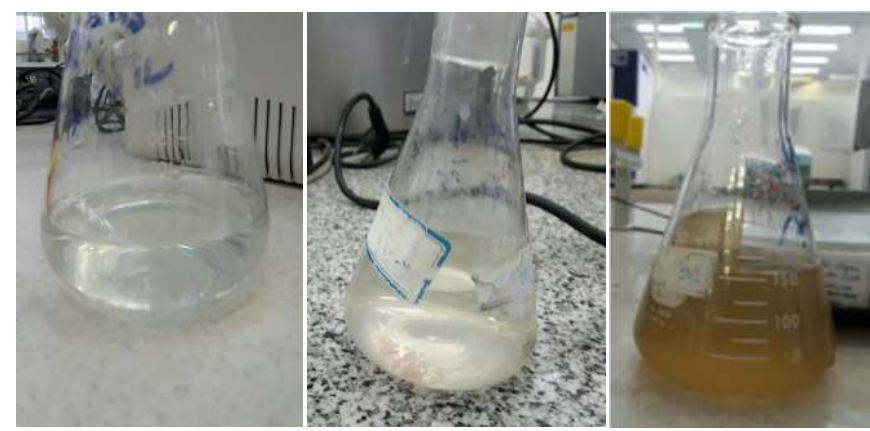


شكل ه: تصاوير رنخ فاضلاب تصفيهشده طى فرايند تقطير (از راست به جِّ به ترتيب مراحل ا تا ؟).

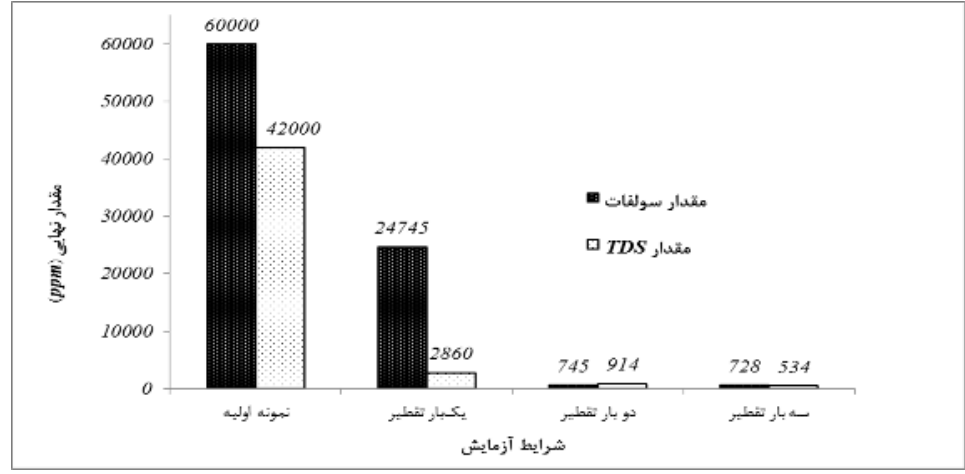

شكل \&: نتايج تصفيه به كمك روش تقطير

در جريان است و خوراك ورودى به سيستم نيز با نـرخ از دماى ورودى Thf تا نقطه جوش Th افزايش دما بيـدا مسى كنـد. بنابراين ميزان انرزى حرارتى طـى فرآينـد تبخيـــ از فرمـول 9

$$
\text { قابل محاسبه است: }
$$

$$
Q=M_{f} C_{p}\left(T_{b}-T_{f}\right)+M_{d} \lambda_{V}=M_{S} \lambda_{S}
$$

كه در معادلـه فـوق Q ميـزان انـرزى كرمـايى، $C_{p}$ ميـزان ظرفيت گرمايى خور اك (فاضلاب)، كرمان نهان تبخير مى باشد 'ا.

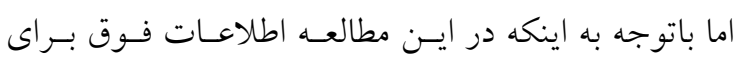
״ِاب مورد مطالعه دردسترس نبـوده اسـت، محاسـبه گرمـاى لازم براى تبخير و در نهايت تقطير ميسر نشد.

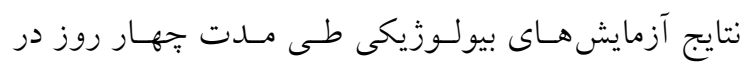
شكل V رسم شده است.
در شكل 7 نتايج تصفيه به روش تقطيـر بصـورت نمـودار ستونى مشاهده مى شود. جهت محاسبه ميزان انـرزى مصـرف شـده بـراى سيسـتم تقطير مورد استفاده در اين يزّوهش مىتــوان از تـوان مصـرفى

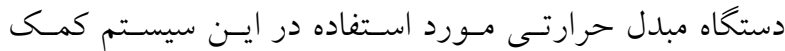
كرفت. با توجه به اينكه در اين ب مرحله از فراينــ تقطيـر بــه طور تقريبى سيستم به مدت r ساعت در حال كار بوده اسـت، ميزان انرزى مصرفى براى اين مقدار سيستم kj ع.بr بــرآورد خواهد شد.

اخرجه ميزان انرزى مصرفى جهت فرايند تقطير را مىتوان باتوجه به ميزان انرزى حرارتى مصرفى بدست آورد امـا، ايسن ميزان انرزى تحت اثر عواملى جون نوع خوراى ورودى (آب، يساب يا آب دريا)، ميزان نمك، بخار تشكيل شده و حـرارت Ms بخار تشكيل شده مى باشد. در سيستم تبخير بخار با نـرخ

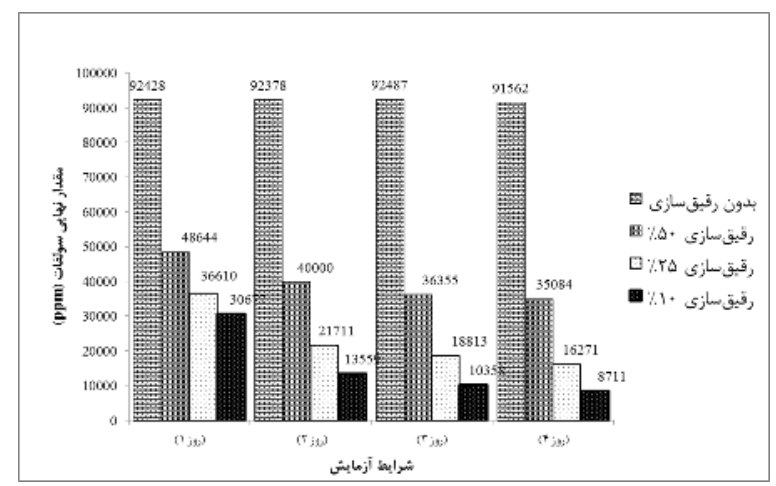




\section{شكل V: نتايج آزمايشات تصفيه به كمك روش بيولوزيكى}

مرتبط بــا مدلســازى فراينـدهاى ترسـيب شـيميايى مسى توانــ عملكرد اين فرايندها را قبل از خريد مــواد شـيميايى و انجـام فرايند آزمايش نمايد.

در مطالعاتى كه بيشتر انجامشده نشاندهنده اين است كه سيستم انعقاد الكتريكى براى غلظـتهـاى بـايين از سـولفات ياسخحو مىباشد طورى كـهـ هوشـيار حسـينى و همكـاران در

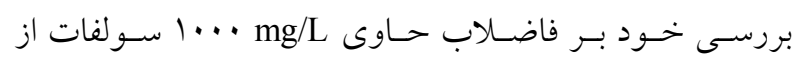

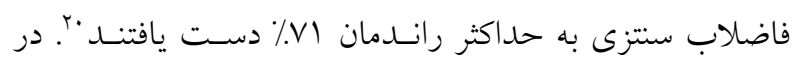

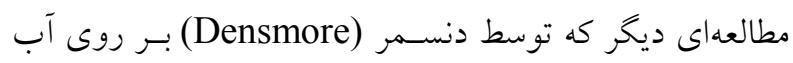

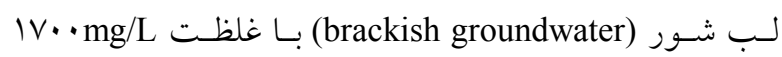
سولفات و با جُخالى جريان VmA/cm² انجامشد، به ميانخين

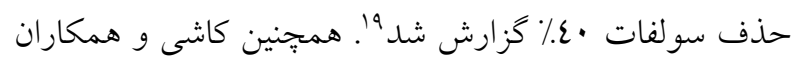
در مطالعهاى كه بر روى حذف سولفات از نمونه آبسى حساوى

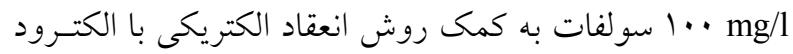

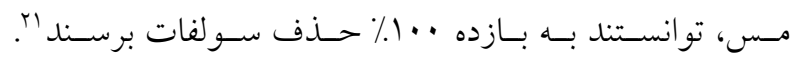

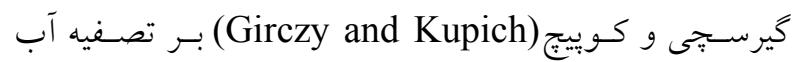
آلوده از نقاط مختلف معدن آهـن بــا غلظـت بـالاى سـولفات

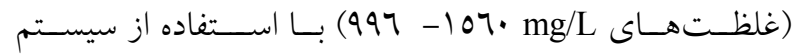
الكتروشيميايى مطالعه نموده و دريافتند كه لختسه هيدروكسيد

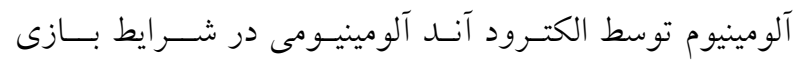
توليــ و يـون سـولفات بـهــورت سـولفات كلسـيم در pH

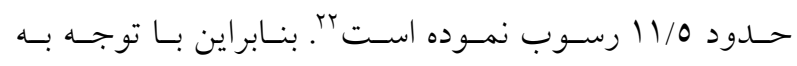
مطالعـات بيشـين مسى تـوان كفـت روش انعقــاد الكتريكـى را

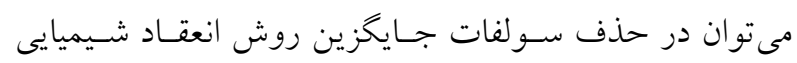

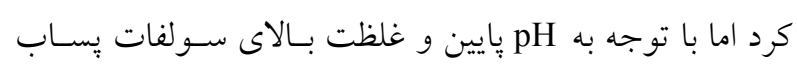

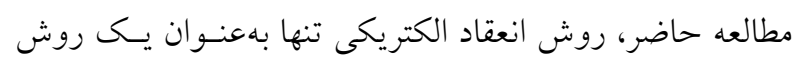

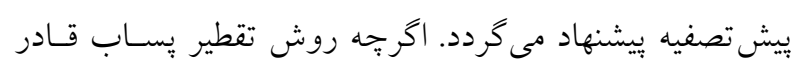
به حذف مقادير بالايى از سولفات است اما براى حذف ـ . 1٪ سولفات و توليد د/ب ليتر آب خالص نياز به ع ساعت حرارت دهى بساب مىباشد كه اين بــان معنىى اسـت حــذف كامـل
همانطور كه مشاهده مىشود با افزايش زمانمانـــ در هـر جهار نمونـه ميـزان حسـف سـولفات افـزايشيافتـه اسـت. در حدفاصـل روز اول بـهروز دوم ميـزان حـذف بـالاتر از سـاير روزها بوده است كه نشانكر عملكرد باكترىهاى SRB موجود درلجن در ع ساعت اول دارد. درصدهاى حذف سولفات در

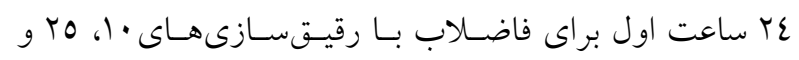

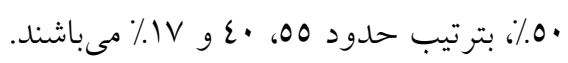

\section{بحث}

طبق مطالعهاى كه در كشور آفريقاى جنـوبى بـر فاضـلاب حاوى mg/L . ..." سولفات حاصل از صـنعت معـدن انجـام

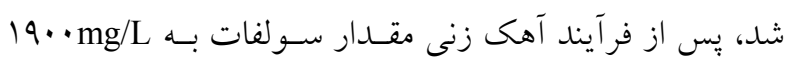
كاهش يافت؛ كه اين بيانخر آن است كه آهك زنى را مىتـوان

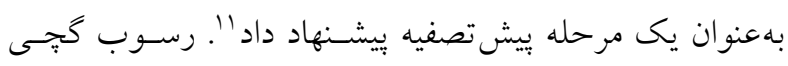

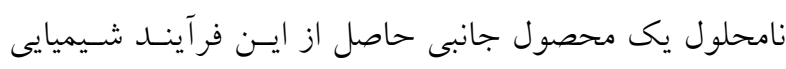
مسىباشــ كـه بـه دليـل تغييـر pH كـه رخ مسى دهـد، حاصـل

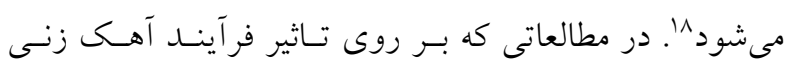
جهت كاهش سولفات در صنايع معدن انجامگرفت، اين نتيجه

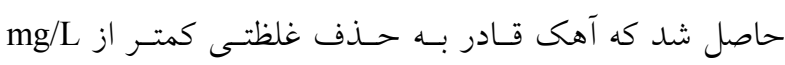

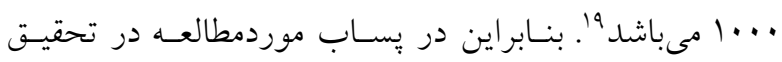
حاضر همانطوركه ذكر شد بـه دليـل غلظـت بـالاى سـولفات (0..........mg/L)، ميزان حذف سولفات بسـيار نـاجيز مشاهده شد، همجنين حجم رسوبات گجى حاصـل از فراينــ

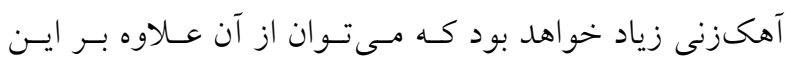

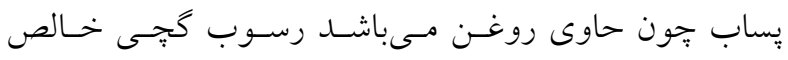

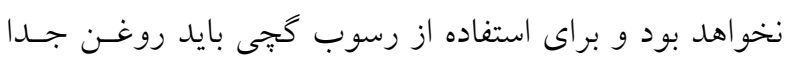

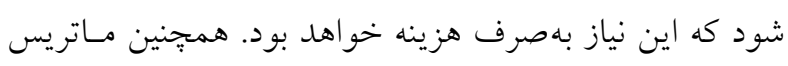

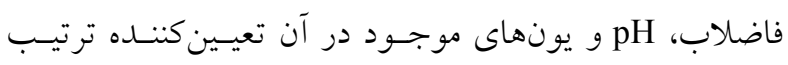

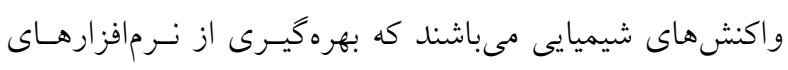




\section{تتيجه گيرى}

در اين يزوهش روشهاى مختلف تصفيه فاضلاب حساوى سولفات موردمطالعه و بررسى قرار كفت. با توجـه بــه مقـادير

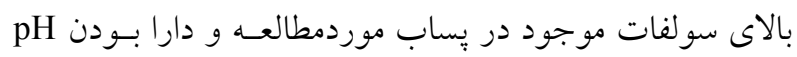

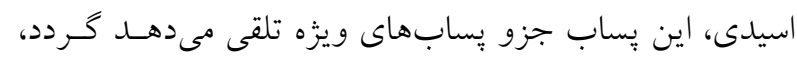

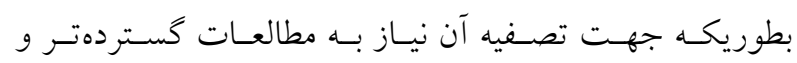
بررسى هاى بيشتر است. همجنين تنها يك روش تصـفيه بـراى

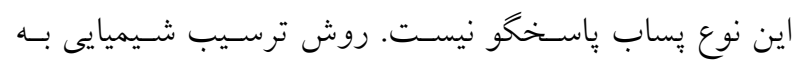

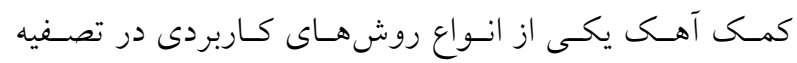
فاضلابهاى حاوى سولفات است اما با توجه بـهويـزه بـودن اين نوع بِاب تنها مىتوان بهعنوان يك روش بيش تصفيه آنرا بيشنهاد نمود. جهت مرحله نهايى تصـفيه از روش بيولـوزيكى

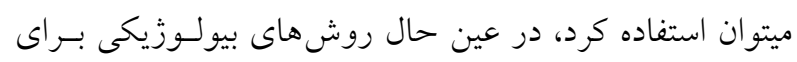
حذف بيولوزيكى سولفات در غلظتهاى اوليه بالا سبب ايجاد سميت براى باكترىها مى گردد كه براى جلـو گيرى از مسـئله،

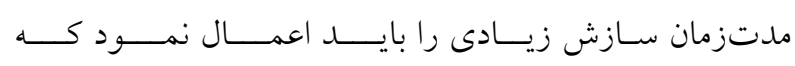
ايسـن موضـــوع از محســوديتهــاى ايسن روش محسـوب مى گردد. ساير روش هاى تصـفيهاى موردمطالعـه داراى هزينـه

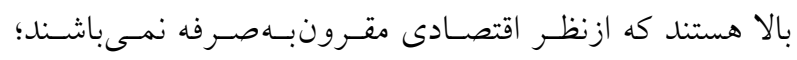
بنابراين براى تصفيه كامل فاضلاب با اين شرايط ويزه نيـاز بـهـ

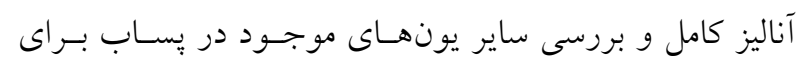

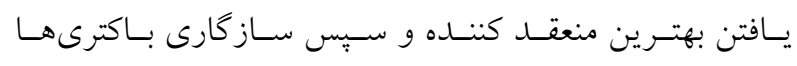

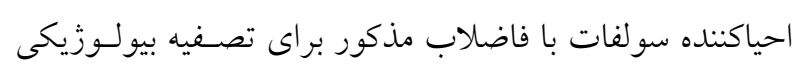

\section{References}

1. Ahmadi M, Tajrishi M, Abrishamchi A. Technical and Economic comparison of conventional wastewater treatment systems in the sugar industries in Iran. J Water Wastewater 2005;53:54-61.[In Persian]

2. Alavi SZ, Mojtahedzadeh H, Amin F SA. Relationship
سولفات نيازمند صرف انرزى زياد و به دنبال آن صرف هزينسه بالاست بَّ. بنابراين در متون علمى اين روش براى مقادير بالاى حذف سولفات موردمطالعه قرار نخرفته است. جنـ (Jong)

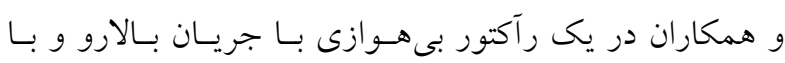
اسـتفاده از باكترىهاى SRB ميزان احيـاى سـولفات (غلظـت

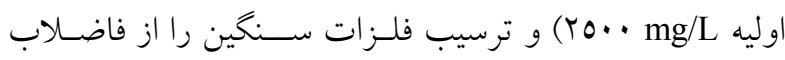
صنعت معدن موردمطالعه قراردادند و سـولفات را بـه ميـزان

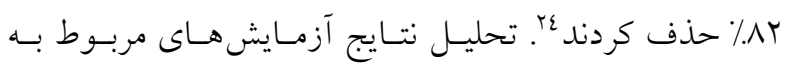
امكانسنجى حذف و كاهش يونهاى سولفات در يُاب واحد

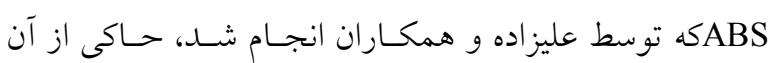
است استفاده از روش هاى بيولـوزيكى يكـى از مناسـبـتـرين كزينهها براى كنترل يُساب محتوى سـولفات مسىباشــــ نتـايج

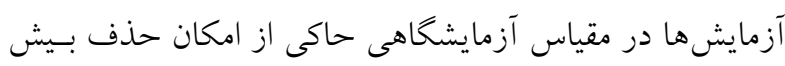

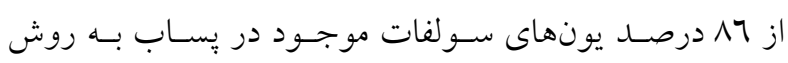
بيولوزيكى غير هوازى مىباشد ب. بنابراين با توجه به مطالعات

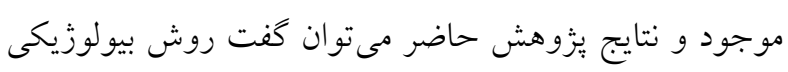

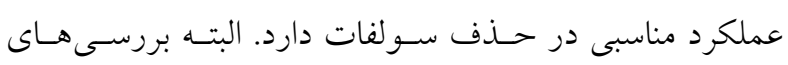
مقدماتى جهت نيل به بازده بـالا در فراينــ احيـاء بيولـوزيكى

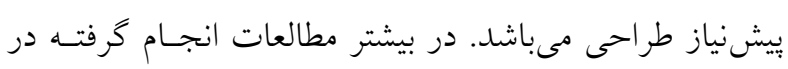
زمينه تصفيه يُاب به كمك روش تقطير، روش مورد اسـتفاده

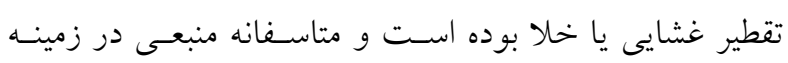

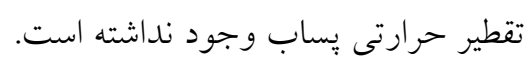

تقدير و تشكر

نويسند گان مقاله حاضر از يزوهشخاه مواد و انرزى بابـت حمايت مالى انجام شده تشكر و قدردانى مى نمايند.

between emotional intelligence and organizational commitment in Iran's Ramin thermal power plant. Procedia. Soc Behav Sci 2013;84:815-9.

3. Dou W, Zhou Z, Jiang L, Jiang A, Huang R. Sulfate removal from wastewater using ettringite precipitation : Magnesium ion inhibition and process optimization. $\mathrm{J}$ 


$$
\text { ليلا داوريناه و همكاران }
$$

Environ Manage 2017;196:518-26.

4. Cao, W., Dang, Z., Zhou, X.Q., Yi, X.Y., Wu, P.X., Zhu, N.W., Lu GN. Removal of sulphate from aqueous solution using modified rice straw: preparation, characterization and adsorption performance. Carbohydr Polym 2011;85:571-7.

5. Mamelkina MA, Cotillas S, Lacasa E, S??ez C, Tuunila R, Sillanp???? M, et al. Removal of sulfate from mining waters by electrocoagulation. Sep Purif Technol 2017;182:87-93.

6. Enviromental L. Treatment of Sulphate in Mine Effluents. Executive Summary, Sulphate Treatment Technoly. 2003;(October):1-129.

7. Bazrafshan E, Kord Mostafapour F F, M, Ownagh K JMH. Application of Combined Chemical CoagulationElectro Coagulation Process for Treatment of the Zahedan Cattle Slaughterhouse Wastewater. Iran J Health Environ 2012;5(3):283-94. [In Persian]

8. Moussavi G, Majidi F FM. The influence of operational parameters on elimination of cyanide from wastewater using the electrocoagulation processs. Desalination 2011;280(1):127-33.

9. Daneshvar N, Oladegaragoze A D, N. Decolorization of basic dye solutions by electrocoagulation: an investigation of the effect of operational parameters. J Hazard Mater 2006;129(1):116-22.

10. C.B.Shivayogimath PK. Treatment of Tannery Effluent Using Electrocoagulation. Int J Innov Res Sci Eng Technol 2015;4(7):1409-15.

11. RJ B, RJ C, J E, J C, Wood A, Barta J EP. A review of sulfate removal options for mine waters, In Mine water. Proc Int Mine Water Assoc Symp. 2004;2:75-91.

12. Ma J, Ma Z, Yan J, Ni M, Cen K. Development of an evaporation crystallizer for desalination of alkaline organic wastewater before incineration. J Zhejiang Univ Sci 2005;6A(10):1101-6.

13. McCabe DL, Vivona MA. Treating process wastewater employing vacuum distillation using mechanical vapor recompression. Environ Prog 1999;18(1):30-3.
14. Georgiou D, Georgiou D, Aivazidis a, Aivazidis a, Hatiras J, Hatiras J, et al. Treatment of cotton textile wastewater using lime and ferrous sulfate. Water Res 2003;37:2248-50.

15. Annual Book of ASTM Standards, Part 31, "Water," Standard D516-68, Method B, p. 430 (1976).

16. Standard Methods for the Examination of Water and Wastewater, 14th ed., p . 496, Method 427C, (1975).

17. El-Dessouky HT, Ettouney HM. Fundamentals of Salt Water Desalination 2002. 24 p.

18. Tahija ,D $\backslash$, Huang, H-H., Flores, C., and Shi Y. On the treatment of Berkerley Pit Water. Proceedings Mineral and Hazardous Waste Processing Symposium. Butte Mont. 1990.

19. Geldenhuys, A.J., Maree, J.P., de Beer, M. and Hlabela P. An integrated limestone/lime process for partial sulfate removal. Proc Environ Responsible Min South Africa. 2001;

20. GM. D. Electrocoagulation for sulfate removal. 2015;

21. Giti Kashi, Abbas Rezaii, Ahmad Jafari Joneydi, Alireza Khataii HM. Investigation of the removal of sulfate from drinking water by electrochemical method. In: National Water Conference with Clean Water Approach. 2010. [In Persian]

22. Girczy, J. and Kupich I. Reduction of sulphate ions concentration in discharge waters from $\mathrm{ZnPb}$ mine. Physicochem Probl Miner Process 2006;40:125-34.

23. https://www.lenntech.com/.

24. Jong T PD. Removal of sulfate and heavy metals by sulfate reducing bacteria in short-term bench scale upflow anaerobic packed bed reactor runs. Water Res 2003;37(14):3379-89.

25. A.Alizadeh, F.Seyednajafi. Investigation of the reduction of sulfate ion concentration in the effluent unit effluent effluent Non-aerobic biological treatment. In: First Iranian Petrochemical Conference. 2008. [In persian] 